\title{
Comparation of Bioavailability: Two Dexlansoprazole Formulations in Beagle Dogs after a Single Dose Administration
}

\author{
Jiaqi Zhang, Jinlong Qi, Yaru Wu, Zhongning Zhu, Suwen SU, Xueyan Chen, Yanfang Xu and Qingzhong Jia* \\ Department of Pharmacology, Hebei Medical University, Shijiazhuang, China
}

\begin{abstract}
The study was performed to determine oral bioequivalence of generic dexlansoprazole and reference formulation (Dexilant) in healthy dogs. A 2 period crossover balanced design was used with a 7 days washout period between the doses. Dexlansoprazole was analyzed by LC-MS/MS in the presence of omeprazole as internal standard. The mean ratio of parameters $C_{m a x}$ and $A U C_{0-t}$ and $90 \%$ confidence intervals of correspondents were calculated to determine the bioequivalence. The means $A U_{0-\mathrm{t}}$ for test and reference formulation were $4094.5 \mathrm{ug} / \mathrm{L}^{*} \mathrm{~h}$ and $3684.9 \mathrm{ug} / \mathrm{L}^{*} \mathrm{~h}$, for $\mathrm{AUC}_{0-\infty}$ were $4137.5 \mathrm{ug} / \mathrm{L}^{*} \mathrm{~h}$ and $3709.6 \mathrm{ug} / \mathrm{L}^{*} \mathrm{~h}$ and, for $\mathrm{C}_{\max } 1643.0 \mathrm{ug} / \mathrm{L}$ and $1498.2 \mathrm{ug} / \mathrm{L}$, respectively. Geometric mean of the test /reference Pharmaceuticals $30 \mathrm{mg}$ formulation individual percent ratio was $99.3 \%$ for $\mathrm{AUC}_{0-\mathrm{t}}, 100.6 \%$ for $\mathrm{AUC}_{0-\infty}$ and $110.0 \%$ for $\mathrm{C}_{\text {max }}$. The $90 \%$ confidence intervals were $84.0 \% \sim 117.5 \%, 85.3 \% \sim 118.7 \%, 85.0 \% \sim$ $142.3 \%$, respectively. It was concluded that pharmacokinetic data for test formulation were similar enough to original innovator, both formulations had the delayed releasing and double peak characteristics in dogs according to the rate and extent of absorption.
\end{abstract}

Keywords: Bioequivalence; Dexlansoprazole; LC-MS/MS; Pharmacokinetics

\section{Introduction}

Helicobacter pylori (H. pylori), first isolated in 1984, was found parasitic in gastric mucosa, inducing upper gastrointestinal diseases such as gastritis, peptic ulcer, gastroesophageal reflux disease and gastric cancer. It was reported that early detection, timely and effectively take antibiotics could prevent and control upper digestive system diseases to a great extent. Years past $H$. pylori has been found to be a bacteria which is difficult to treat, and it also obtained the resistance of common used antibiotics [1-6].

Modern treatments are effective in managing the symptoms of the gastrointestinal disease, mainly through using antibiotics and PPIs. Dexlansoprazole is the R-enantiomer of lansoprazole. The reference formulation adopts an innovative Dual Delayed Release (DDR) delivery system, designing to extend the duration of drug exposure and maintain pharmacologically active levels of drug over a longer period of time, resulting in a dexlansoprazole plasma concentration-time profile with two distinct peaks. The levofloxacin-dexlansoprazole based quadruple therapy provides high $H$. pylori eradication for clarithromycin or dual clarithromycin and metronidazole resistant strains. This regimen could be used as an alternative first line therapy for $H$. pylori eradication. Dexlansoprazole appears to be effective in improving heartburn, regurgitation and maintained for the duration of the treatment $[6,7]$.

The pharmacokinetic parameters for dexlansoprazole have been acquired fromclinical trials including healthy subjects and patients. For reducing the $\mathrm{R} \& \mathrm{D}$ risk and cost of a generic drug product, using Beagle dogs as the preclinical subjects to evaluate bioequivalence is an effective and fast way. In this study, a simple, rapid and sensitive LCMS/MS method was developed and validated for the determination of dexlansoprazole $30 \mathrm{mg}$ capsules after oral administration in beagle plasma, and it is helpful to make a forward clinical research.

\section{Methods}

\section{Subjects}

Six males and six females pure bred beagle dogs were purchased from Beijing Marshall Biotechnology Co. Ltd. (the qualification card number
11400600000678). The animal room was maintained at a temperature of $18-25^{\circ} \mathrm{C}$, with a relative humidity of $40-70 \%$ and a $12 \mathrm{~h}$ light/dark cycle. Prior to the initiation of dosing, the dogs were quarantined for 2 weeks and then acclimatized to the study environmental conditions before use. The dogs were fed $300 \mathrm{~g}$ certified commercial diet (Vital River, Charles River China, PR China) at a fixed time per day and tap water ad libitum during the study. Each dog was individually housed in an elevated stainless-steel cage and exercised in compliance with the Animal Welfare Act requirements accordance with NIH guideline (NRC, 1996). The study was approved by the Ethical Committee of the Faculty of Veterinary Medicine and carried out in the Center for New Drug Safety Evaluation and Research of Hebei Medical University (GLP certificated lab.).

\section{Drug products}

The employed test formulation was dexlansoprazole manufactured by Pharmaceutical factory of Hebei Medical University $30 \mathrm{mg}$ (lot number 140501) and the reference formulation was manufactured by Takeda Pharmaceuticals America Inc. 30 mg (lot number C20674).

\section{Study design}

The study was conducted in a randomized 2 period crossover balanced design with 7 days wash out period between the doses. During each period, the animals were fed at 5:00 pm, and after an overnight fast they received a single $30 \mathrm{mg}$ capsule dexlansoprazole dose of either formulation at 8:00 am. All dogs proceed fast $3 \mathrm{~h}$ following the drug administration, but liquid consumption was permitted.

*Corresponding author: QZ Jia, Professor, Department of Pharmacology, Hebei Medical University, No. 361 East Zhongshan Road, Shijiazhuang, Hebei 050017, Tel: (86)-311-86265644; E-mail: qizhjia@hebmu.edu.cn

Received March 11, 2016; Accepted April 17, 2016; Published April 24, 2016

Citation: Zhang J, Qi J, Wu Y, Zhu Z, Suwen SU, et al. (2016) Comparation of Bioavailability: Two Dexlansoprazole Formulations in Beagle Dogs after a Single Dose Administration. J Bioequiv Availab 8: 140-144. doi:10.4172/jbb.1000284

Copyright: ( 2016 Zhang J, et al. This is an open-access article distributed under the terms of the Creative Commons Attribution License, which permits unrestricted use, distribution, and reproduction in any medium, provided the original author and source are credited. 
Blood samples from a suitable leg vein were collected into vacuum heparin containing tube with scale before and 0.5,1.0, 1.5, 2.0, 2.5, 3.0, 4.0, 5.0, 6.0, 8.0, 10.0, $12.0 \mathrm{~h}$ after administration of each dexlansoprazole $30 \mathrm{mg}$, and collect blood for $3 \mathrm{ml}$ in each time point.

\section{Drug analysis}

Blood samples were cooled in a bath and centrifuged at $3000 \mathrm{rpm}$ for at least $10 \mathrm{~min}$ at approximately $4^{\circ} \mathrm{C}$. Sample tubes were frozen at $-80^{\circ} \mathrm{C}$, and maintained to that temperature until analysis (delivery to the analytical phase). All samples from a single beagle were analyzed on the same day in order to avoid inter assay variation.

Plasma concentrations of dexlansoprazole were determined by the HPLC coupled with tandem mass spectrometry (LC-MS/MS), in positive ion electrospray ionization mode, using a multiple monitoring (MRM) method andomeprazole as internal standard (IS) due to its similar extraction efficiency and ionization efficiency to dexlansoprazole. The transitions used were $369.8 \rightarrow 252.0$ for Dexlansoprazole and 345.9 $\rightarrow 198.0$ for IS. This apparatus consisted of an SHIMADZU LC-30A liquid chromatography system, with pump, automatic injector, oven and SCIEX AB API4000Q-Trap mass spectrometer with ESI. Use liquid-liquid extraction obtaining the analytes from plasma samples. The method was validated for specificity, linearity, precision, accuracy, extraction recovery and matrix effect, stability and dilution integrity. The analytical column was a Synergi Fusion-RP C18, $4 \mu \mathrm{m}, 50 \times 3.0$ $\mathrm{mm}$ (phenomenex). The mobile phase consisting of methanol (A) and Buffer (ammonium acetate $2 \mathrm{mM}$ ) (B) was delivered for separation of analytes using a gradient elution program at a flow rate of $0.5 \mathrm{~mL} / \mathrm{min}$. The gradient elution program was conducted as follows: 0-1.4 min, $65 \%$ A; $1.4-2.5 \mathrm{~min}, 65 \%-95 \% \mathrm{~A}$. The auto-sampler was maintained at $4^{\circ} \mathrm{C}$ and the injection volume was $5 \mu \mathrm{L}$.

\section{Pharmacokinetic analysis and statistical analysis}

The pharmacokinetic parameters were calculated according to non-compartment model and were analyze dusing the DAS Institute (Version 3.2.6): Including half-life $\left(\mathrm{t}_{1 / 2}\right)$, total body clearance/F (CLz/F), steady state apparent volume of distribution/F (Vz/F). Maximum concentration $\left(\mathrm{C}_{\max }\right)$, time-to-maximum concentration $\left(\mathrm{T}_{\max }\right)$ were obtained directly from the curves. Area under curve from zero to the last measurable plasma concentration point $\left(\mathrm{AUC}_{0-\mathrm{t}} \mathrm{t}=12 \mathrm{~h}\right.$ for p.o. administrations) and area under the plasma concentration-time curve from zero to time infinity $\left(\mathrm{AUC}_{0-\infty}\right)$ were calculated by applying the linear trapezoidal rule and ratio of $\mathrm{AUC}_{0-\mathrm{t}} / \mathrm{AUC}_{0-\infty}\left(\mathrm{R} \_\mathrm{AUC}_{(\mathrm{t} / \infty)}\right)$.

The bioequivalence between both formulations was assessed by calculating individual $\mathrm{C}_{\max }, \mathrm{AUC}_{0-\mathrm{t}}, \mathrm{AUC}_{0-\infty}$ together with their mean and $90 \%$ confidence intervals (CI) after log transformation of the data. The inclusion of the $90 \%$ CI for the ratio in the $80 \%$ to $125 \%$ range (for $\mathrm{AUC}_{0-\mathrm{t}}, \mathrm{AUC}_{0-\infty}$ ) and $70 \%$ to $143 \%$ range (for $\mathrm{C}_{\max }$ ) was analyzed by nonparametric (DAS Institute Version 2.1.1) and parametric (ANOVA) methods.

\section{Results}

\section{Method validation}

The calibration curves $(r \geq 0.9960, r$ was the correlation coefficient $)$ were linear in the ranges of $5-1200 \mathrm{ng} / \mathrm{mL}$ by using least square linear regression analysis with a weight factor of $1 / \mathrm{x}^{2}$. The lower limit of quantification (LLOQ) for Dexlansoprazole in dog plasma was $5 \mathrm{ng} /$ $\mathrm{ml}$, respectively, based on a signal-to-noise ratio $(\mathrm{S} / \mathrm{N})$ of 10 , and the intra-day precision (RSD\%) was $4.54 \%(\mathrm{n}=6)$ and accuracy $(\mathrm{RE} \%)$ was $8 \%$. The limit of detection (LOD) was $1 \mathrm{ng} / \mathrm{ml}$, respectively based on an $\mathrm{S} / \mathrm{N}$ of 3 . The accuracy and precision of the method were evaluated by determining replicate QC samples $(8,200$ and $800 \mathrm{ng} / \mathrm{ml}$ ) on three days. The precision of intra and inter day RSDs were no more than $15.43 \%$, and the accuracy ranged from $-3.0 \% \sim 4.4 \%$ (Table 1 ), indicating acceptable precision and accuracy of the present method.

The extraction recoveries of dexlansoprazole (for the three quality control concentration of 8,200 and $800 \mathrm{ng} / \mathrm{ml}$ ) and IS from beagle plasma were $109.48 \%, 93.79 \%, 95.63 \%$ and $92.90 \%$, respectively. The matrix effect of dexlansoprazole (for the quality control concentration of 8,200 and $800 \mathrm{ng} / \mathrm{ml}$ ) and IS were $105.61 \%, 106.08 \%, 99.06 \%$ and $111.16 \%$. The stability of analytes in plasma of dexlansoprazole were accessed and found short term stability for $4 \mathrm{~h}\left(25^{\circ} \mathrm{C}\right)$, autosampler for $8 \mathrm{~h}\left(4^{\circ} \mathrm{C}\right)$ and long term stability for $6,15,30$ days $\left(-80^{\circ} \mathrm{C}\right)$ and during the one and three freeze and melt cycles (Table 2) indicated the good stability of dexlansoprazole during the study.

\section{Pharmacokinetic and statistical analysis}

The mean $( \pm$ SD) plasma concentration time profile of the 2 formulations, shown in Figure 1, was similar.

Central and dispersion measures for all pharmacokinetic parameters for both formulations are shown in Tables 3 and 4 . From this, the mean values of $\mathrm{C}_{\text {max }}$ were found to be 1498.2 ( \pm 876.9 standard deviations [SD] $) \mathrm{ng} / \mathrm{mL}$ for the reference product and $1643.0( \pm 988.8) \mathrm{ng} / \mathrm{mL}$ for the test product. For $\mathrm{T}_{\max }(\mathrm{h})$, the mean values were found to be similar to both the reference and test product and the value was $2.0(1.7) \mathrm{h}$. The mean values of $\mathrm{AUC}_{0-\mathrm{t}}$ were found to be 3684.9 ( \pm 1761.5$) \mathrm{ng} . \mathrm{h} / \mathrm{mL}$ for reference and $4094.5( \pm 3259.6) \mathrm{ng} . \mathrm{h} / \mathrm{mL}$ for the test product. The mean $\mathrm{AUC}_{0-\infty}$ was found to be $3709.6( \pm 1770.5) \mathrm{ng} . \mathrm{h} / \mathrm{mL}$ and 4137.5 $( \pm 3251.0) \mathrm{ng} . \mathrm{h} / \mathrm{mL}$ for the reference and the test product, respectively. Table 5 presents the ratios and the respective confidence intervals for bioequivalence analysis.

\section{Discussion}

Gastroesophageal reflux disease (GERD) is a clinical condition characterized by persistent retrograde movement of gastric contents into the esophagus that typically manifests as burning retrosternal pain and/or regurgitation. Atypical symptoms of GERD have been described and include chronic cough, vocal hoarseness, globus, water brash, and throat pain that can affect an individual's quality of life (QOL) andor produce complications [8-10].

Proton pump inhibitors (PPIs) are the standard therapy for long-

\begin{tabular}{|c|c|c|c|}
\hline $\begin{array}{c}\text { Nominal Con. } \\
\text { (ng/ml) }\end{array}$ & $\begin{array}{c}\text { Measured Con. } \\
\text { (Mean } \pm \text { SD, ng/ml) }\end{array}$ & $\begin{array}{c}\text { Accuracy } \\
\text { (RE\%) }\end{array}$ & $\begin{array}{c}\text { Intra-day Run } \\
\text { (RSD\%) }\end{array}$ \\
\hline 8.00 & $8.19 \pm 0.62$ & 2.4 & 5.92 \\
\hline 200 & $209 \pm 11$ & 4.4 & 3.69 \\
\hline 800 & $776 \pm 31$ & -3.0 & 15.43 \\
\hline
\end{tabular}


Citation: Zhang J, Qi J, Wu Y, Zhu Z, Suwen SU, et al. (2016) Comparation of Bioavailability: Two Dexlansoprazole Formulations in Beagle Dogs after a Single Dose Administration. J Bioequiv Availab 8: 140-144. doi:10.4172/jbb.1000284

\begin{tabular}{|c|c|c|c|c|}
\hline Storage Conditions & $\begin{array}{l}\text { Nominal Con. } \\
(\mathrm{ng} / \mathrm{ml})\end{array}$ & $\begin{array}{c}\text { Measured Con. } \\
\text { (Mean } \pm \text { SD, } \mathrm{ng} / \mathrm{ml})\end{array}$ & $\begin{array}{l}\text { RSD } \\
(\%)\end{array}$ & $\begin{array}{l}\mathrm{RE} \\
(\%)\end{array}$ \\
\hline \multirow{2}{*}{$4 \mathrm{~h}\left(25^{\circ} \mathrm{C}\right)$} & 8.00 & $7.17 \pm 0.59$ & 8.17 & -8.46 \\
\hline & 800 & $799 \pm 28$ & 3.46 & 0.46 \\
\hline \multirow{2}{*}{ Auto-sampler for $8 \mathrm{~h}\left(4^{\circ} \mathrm{C}\right)$} & 8.00 & $8.37 \pm 0.33$ & 3.99 & 6.76 \\
\hline & 800 & $790 \pm 41$ & 5.15 & -0.71 \\
\hline \multirow{2}{*}{1 freeze and melt cycles } & 8.00 & $7.36 \pm 0.53$ & 7.21 & -6.08 \\
\hline & 800 & $732 \pm 19$ & 2.64 & -7.96 \\
\hline \multirow{2}{*}{3 freeze and melt cycles } & 8.00 & $8.01 \pm 0.54$ & 6.74 & 2.17 \\
\hline & 800 & $774 \pm 59$ & 7.59 & -2.72 \\
\hline \multirow{2}{*}{6 days $\left(-80^{\circ} \mathrm{C}\right)$} & 8.00 & $8.19 \pm 0.72$ & 8.79 & 4.55 \\
\hline & 800 & $785 \pm 8$ & 0.99 & -1.30 \\
\hline \multirow{2}{*}{15 days $\left(-80^{\circ} \mathrm{C}\right)$} & 8.00 & $8.91 \pm 0.36$ & 4.01 & 7.33 \\
\hline & 800 & $754 \pm 30$ & 3.91 & -1.44 \\
\hline \multirow{2}{*}{30 days $\left(-80^{\circ} \mathrm{C}\right)$} & 8.00 & $8.44 \pm 0.66$ & 7.82 & 7.74 \\
\hline & 800 & $829 \pm 39$ & 4.71 & 4.27 \\
\hline
\end{tabular}

Abbreviation: Con.=Concentration

Table 2: Stability of dexlansoprazole in dog plasma under different storage conditions.

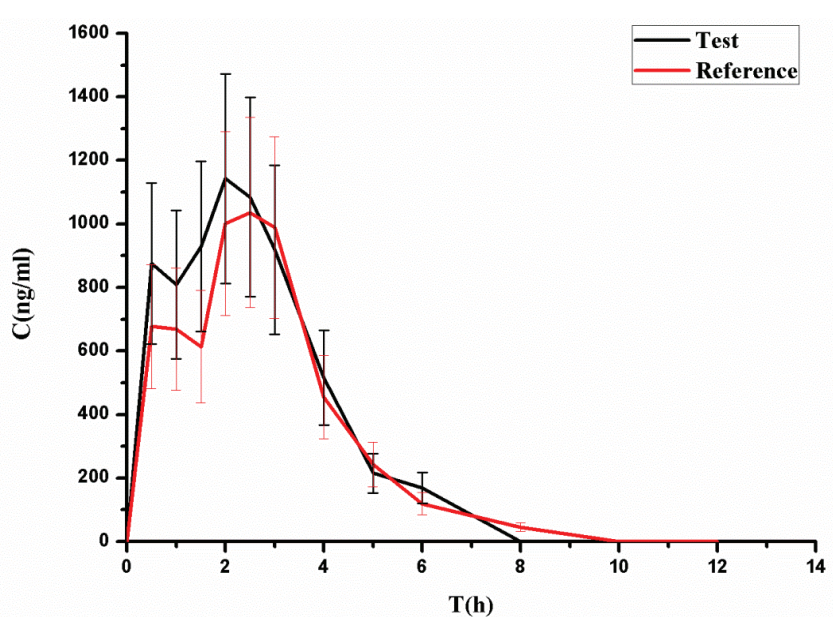

Figure 1: Mean plasma concentration-time profile of dexlansoprazole over the first $12 \mathrm{~h}$ after oral administration of the test formulation.

term management of GERD. Pharmacologic treatment options for GERD have been directed at suppression of gastric acid production in order to reduce both volume and acidity of gastric contents. Anti-secretory agents employed for the treatment of GERD include the histamine-2 receptor antagonists (H2RA) and proton pump inhibitors (PPI). H2RA possess a rapid onset of symptom control and effectively inhibit acid production; however, their use is limited by their brief duration of action and tachyphylaxis possibly owing to histamine-2 receptor up-regulation and enhanced gastrin secretion in the presence of histamine blockade. On the contrary, Proton pump inhibitors (PPIs) block the gastric H, KATPase via covalent binding at different cysteine residues and inhibit gastric acid secretion, and its activity cannot be replaced until a new proton pump is synthesized. Consequently, such agents are also used to treat acid-related conditions such as peptic ulcers, functional dyspepsia and their complications including bleeding, non-steroidal antiinflammatory drug-induced gastrointestinal lesions, etc. Combine with antibiotics, PPIs are also used to eliminate Helicobacter pylori. PPIs have an excellent safety profile, and have become one of the most commonly prescribed class of drugs in both primary and specialty care $[8,11-17]$.

\begin{tabular}{|c|c|c|c|c|}
\hline \multirow[b]{2}{*}{$\begin{array}{l}\text { Parameters } \\
\text { (Units) }\end{array}$} & \multicolumn{2}{|r|}{ Test } & \multicolumn{2}{|c|}{ Reference } \\
\hline & $\begin{array}{c}\text { Means } \\
\text { (Median) }\end{array}$ & $\begin{array}{c}\text { Standard Deviation } \\
\text { (Amplitude) }\end{array}$ & $\begin{array}{c}\text { Means } \\
\text { (Median) }\end{array}$ & $\begin{array}{l}\text { Standard } \\
\text { Deviation } \\
\text { (Amplitude) }\end{array}$ \\
\hline$A \cup C_{(0-t)}($ ug/L*h) & 4095 & 3260 & 3685 & 1762 \\
\hline$A U C_{(0-\infty)}\left(u g / L^{*} h\right)$ & 4138 & 3251 & 3710 & 1771 \\
\hline $\mathrm{C}_{\max }(\mathrm{ug} / \mathrm{L})$ & 1643 & 989 & 1498 & 877 \\
\hline$T_{\max }(h)$ & 2.0 & 1.2 & 1.7 & 1.1 \\
\hline 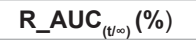 & 98.3 & 2.3 & 99.3 & 0.9 \\
\hline Vz/F (L/kg) & 1.4 & 1.0 & 1.3 & 1.0 \\
\hline CLz/F (L/h/kg) & 1.1 & 0.5 & 1.0 & 0.5 \\
\hline $\mathrm{T}_{1 / 2} \mathrm{z}(\mathrm{h})$ & 0.9 & 0.4 & 0.8 & 0.3 \\
\hline
\end{tabular}

Table 3: Mean pharmacokinetic of parameters dexlansoprazole of test and reference formulation $(n=12)$

\begin{tabular}{|c|c|c|}
\hline $\begin{array}{c}\text { Parameters } \\
\text { (Units) }\end{array}$ & Test & Reference \\
\cline { 2 - 3 } & Geometric mean & Geometric mean \\
\hline AUC $_{(0-t)}$ (ug/L*h) & 3272.61 & 3294.04 \\
\hline AUC $_{(0-\infty)}$ (ug/L*h) & 3340.75 & 3319.55 \\
\hline $\mathbf{C}_{\max }$ (ug/L) & 1400.08 & 1273.01 \\
\hline
\end{tabular}

Table 4: Geometric mean pharmacokinetics parameters of dexlansoprazole of test and references formulation $(n=12)$.

\begin{tabular}{|c|c|c|c|}
\hline Parameters & Ratio T/R (\%) & Lower Limit (\%) & Upper Limit (\%) \\
\hline AUC $_{(0-\mathrm{t})}$ & 99.3 & 84.0 & 117.5 \\
\hline AUC $_{(0-\infty)}$ & 100.6 & 85.3 & 118.7 \\
\hline $\mathbf{C}_{\max }$ & 110.0 & 85.0 & 142.3 \\
\hline
\end{tabular}

Table 5: Bioequivalence evaluation from the ratio means and the $90 \%$ geometric confidence interval of two formulations $(n=12)$.

Lansoprazole is substituted benzimidazoles that contain the asymmetric chiral sulfur atom in their chemical structure and therefore they exist in both form R- and S-enantiomers. Therefore, lansoprazole was initially used as a racemate. Since R-enantiomer of lansoprazole, dexlansoprazole, constitutes more than $80 \%$ of circulating drug after oral administration of racemic drug, provides lower clearance and 5-fold greater systemic exposure than the S-enantiomer. Dexlansoprazole is extensively metabolized in the liver by cytochrome P450 (CYP) enzymesystem, and mainly through CYP2C19. There are genetic differences in the activity of this enzyme, the pharmacokinetics and pharmacodynamics of PPIs are affected by genetic polymorphisms 
of CYP2C19.That may cause the standard deviation in this experiment appears a bit large. The safety profile of dexlansoprazole MR is similar to that of lansoprazole. The extended pharmacodynamic effects, added convenience, and efficacy and safety of dexlansoprazole MR offer a novel approach to gastric $\mathrm{pH}$ control in patients with acid-related disorders [18-22].

Dexlansoprazole MR is a novel modified-release formulation of dexlansoprazole, an enantiomer of lansoprazole, which employs an innovative Dual Delayed Release (DDR) delivery system designed to prolong plasma concentration of dexlansoprazole and provide extended duration of acid suppression with once-daily (q.d.) dosing. The DDR delivery system have two distinct drug release periods in the digestive system, therefore extending plasma concentrations following oral administration. Dexlansoprazole MR capsules contain a mixture of two types of granules, each providing a different $\mathrm{pH}$-dependent dissolution profile. One type of granule is designed to release drug fast after the granules reach the proximal duodenum, while the second is designed to release the remaining dose farther along the digestive system at the distal portion of the small intestine. As a result, dexlansoprazole MR produces a dual-peak PK profile, contrary to the single peak seen with conventional PPIs. To maintain prolonged plasma concentrations, dexlansoprazole MR releases drug over a longer period than conventional delayed release PPIs and thereby requires higher daily doses. Compared with lansoprazole, dexlansoprazole MR achieves higher AUCs without a commensurate increase in $\mathrm{C}_{\max }[7,8,23]$.

The bioavailability of a pharmaceutical form refers to the extent and speed of absorption of the active principle in contained it. Two pharmaceutical forms are said bioequivalent when administered to the same individual, in the same experimental conditions and at the same dose, they show no significant differences in relation to bioavailability. In this study two formulations of dexlansoprazole had been evaluated. Washout period was adequate and there was no quantifiable concentration of the drugs in the second period of the study, indicating that there was no carryover effect from the first to the second period. The mean ratio of parameters $\mathrm{C}_{\max }$ and $\mathrm{AUC}_{0-\mathrm{t}}$ and $90 \%$ confidence intervals of correspondents were calculated to determine the bioequivalence [24].

The analysis method for the quantification of dexlansoprazole in human plasma mainly focus on the LC-MS/MS method, recently, RPHPLC method has been developed and validated for its simple and stability. However, the LC-MS/MS methods appear several original advantages, such as high specificity and sensitivity. In this study by LC-MS method revealed some pharmacokinetic parameter of dexlansoprazole. The means $\mathrm{AUC}_{0-\mathrm{t}}$ for test and reference formulation were $4094.5 \mathrm{ng} . \mathrm{h} / \mathrm{mL}$ and $3684.9 \mathrm{ng} . \mathrm{h} / \mathrm{mL}$, for $\mathrm{AUC}_{0-\infty}$ were $4137.5 \mathrm{ng} . \mathrm{h} /$ $\mathrm{mL}$ and $3709.6 \mathrm{ng} . \mathrm{h} / \mathrm{mL}$ and, for $\mathrm{C}_{\max } 1643.0 \mathrm{ng} / \mathrm{mL}$ and $1498.2 \mathrm{ng} / \mathrm{mL}$, respectively. The ratios were $99.3 \%$ for $\mathrm{AUC}_{0-\mathrm{r}}, 100.6 \%$ for $\mathrm{AUC}_{0-\infty}$ and $110.0 \%$ for $\mathrm{C}_{\max }$. The $90 \%$ confidence intervals were $84.0 \% \sim 117.5 \%$ for $\mathrm{AUC}_{0-\mathrm{t}}, 85.3 \% \sim 118.7 \%$ for $\mathrm{AUC}_{0-\infty}$ and $85.0 \% \sim 142.3 \%$ for $\mathrm{C}_{\max }[25]$.

The $\mathrm{AUC}_{0-\mathrm{t}}$ and $\mathrm{AUC}_{0-\infty}$ are both recognized as an uncontaminated measurement of the extent of absorption. The present study showed that $90 \% \mathrm{CI}$ of mean $\mathrm{AUC}_{0-\mathrm{t}}$ and $\mathrm{AUC}_{0-\infty}$ (after log-transformation of individual ratios) were included into the bioequivalence range (80$125 \%$ ), consequently, the two formulations of dexlansoprazole are equivalent for the extend of absorption.

The statistical comparison of $\mathrm{C}_{\max }, \mathrm{AUC}_{0-\mathrm{t}}$ and $\mathrm{AUC}_{0-\infty}$ clearly indicated no significant difference in the two formulations of dexlansoprazole $30 \mathrm{mg}$ delayed release capsules. $90 \%$ confidence intervals for the mean ratio (T/R) of $\mathrm{C}_{\max }, \mathrm{AUC}_{0-\mathrm{t}}$ and $\mathrm{AUC}_{0-\infty}$ were entirely within CFDA acceptance range. Based on the pharmacokinetic and statistical results of this study, we can conclude that the generic dexlansoprazole used in this study was bioequivalent to the original innovator dexlansoprazole.

\section{Acknowledgement}

This research work was financially supported by Hebei provincial foundation including Education Department (NO. GCC2014038) and Science and Technology Agency (NO.12276405D).

\section{References}

1. Marshall BJ, Warren JR (1984) Unidentified curved bacilli in the stomach of patients with gastritis and peptic ulceration. Lancet 1: 1311-1315.

2. Rauws EA, Tytgat GN (1990) Cure of duodenal ulcer associated with eradication of Helicobacter pylori. Lancet 335: 1233-1235.

3. Parsonnet J, Friedman GD, Vandersteen DP, Chang $\mathrm{Y}$, Vogelman $\mathrm{JH}$, et al (1991) Helicobacter pylori infection and the risk of gastric carcinoma. N Engl J Med 325: 1127-1131.

4. Bayerdorffer E, Neubauer A, Rudolph B, Thiede C, Lehn N, et al. (1995) Regression of primary gastric lymphoma of mucosa-associated lymphoid tissue type after cure of Helicobacter pylori infection. MALT Lymphoma Study Group. Lancet 345: 1591-1594.

5. Vilaichone RK, Mahachai V (2001) Current management of Helicobacter pylori infection. J Med Assoc Thai 84 Suppl 1: S32-38.

6. Prapitpaiboon H, Mahachai V, Vilaichone RK (2015) High Efficacy of Levofloxacin-Dexlansoprazole-Based Quadruple Therapy as a First Line Treatment for Helicobacter pylori Eradication in Thailand. Asian Pac J Cancer Prev 16: 4353-4356.

7. Metz DC, Vakily M, Dixit T, Mulford D (2009) Review article: dual delayed release formulation of dexlansoprazole MR, a novel approach to overcome the limitations of conventional single release proton pump inhibitor therapy. Aliment Pharmacol Ther 29: 928-937.

8. Wittbrodt ET, Baum C, Peura DA (2009) Delayed release dexlansoprazole in the treatment of GERD and erosive esophagitis. Clin Exp Gastroenterol 2: 117128

9. Vakil N, van Zanten SV, KahrilasP, Dent J, Jones R (2006) The Montrea definition and classification of gastroesophageal reflux disease: a global evidence-based consensus. Am J Gastroenterol 101: 1900-1920.

10. DabholkarAH, HanC, ParisMM, PerezMC, AtkinsonSN, et al. (2011) The 12 month safety profile of Dexlansoprazole, a proton pump inhibitor with dual delayed release formulation, in patients with gastro-oesophageal reflux disease. Aliment Pharmacol Ther 33: 366-377

11. Gillen D, McColl KE (2001) Problems related to acid rebound and tachyphylaxis. Best Pract Res Clin Gastroenterol 15: 487-495.

12. Novotna A, Srovnalova A, Svecarova M, Korhonova M, Bartonkova I, et al. (2014) Differential effects of omeprazole and lansoprazole enantiomers on aryl hydrocarbon receptor in human hepatocytes and cell lines. PLoS One 9 . e98711.

13. Sachs G, Shin JM, Besancon M, Prinz C (1993) The continuing development of gastric acid pump inhibitors. Aliment Pharmacol Ther 7 Suppl 1: 4-12 discussion 29-31.

14. Shin JM, Sachs G (2004) Differences in binding properties of two proton pump inhibitors on the gastric $\mathrm{H}+, \mathrm{K}+-A T P a s e$ in vivo. Biochem Pharmacol 68: 2117 2127.

15. Park CH, Kim EH, Roh YH, Kim HY, Lee SK (2014) The association between the use of proton pump inhibitors and the risk of hypomagnesemia: a systematic review and meta-analysis. PLoS One 9: e112558.

16. Sheen E, Triadafilopoulos G (2011) Adverse effects of long-term proton pump inhibitor therapy. Dig Dis Sci 56: 931-950.

17. Howden CW, Larsen LM, Perez MC, Palmer R, Atkinson SN (2009) Clinical trial: efficacy and safety of Dexlansoprazole MR 60 and $90 \mathrm{mg}$ in healed erosive oesophagitis-maintenance of healing and symptom relief. Aliment Pharmacol Ther 30: 895-907. 
Citation: Zhang J, Qi J, Wu Y, Zhu Z, Suwen SU, et al. (2016) Comparation of Bioavailability: Two Dexlansoprazole Formulations in Beagle Dogs after a Single Dose Administration. J Bioequiv Availab 8: 140-144. doi:10.4172/jbb.1000284

18. Lee RD, Mulford D, Wu J, Atkinson SN (2010) The effect of time-of-day dosing on the pharmacokinetics and pharmacodynamics of dexlansoprazole MR: evidence for dosing flexibility with a Dual Delayed Release proton pump inhibitor. Aliment Pharmacol Ther 31: 1001-1011.

19. Hotha KK, Vijaya Bharathi D, Jagadeesh B, Ravindranath LK, Jaya Veera $\mathrm{KN}$, et al. (2012) Development and validation of a highly sensitive LC-MS/MS method for quantitation of dexlansoprazole in human plasma: application to a human pharmacokinetic study. Biomed Chromatogr 26: 192-198.

20. Katsuki H, Yagi H, Arimori K, Nakamura C, Nakano M, et al. (1996) Determination of $\mathrm{R}(+)$ - and $\mathrm{S}(-)$-lansoprazole using chiral stationary-phase liquid chromatography and their enantioselective pharmacokinetics in humans. Pharm Res 13: 611-615.

21. Furuta T, Sugimoto M, Shirai N, Ishizaki T (2007) CYP2C19 pharmacogenomics associated with therapy of Helicobacter pylori infection and gastro-esophageal reflux diseases with a proton pump inhibitor. Pharmacogenomics 8: 1199-1210.
22. Nagahara A, Suzuki T, Nagata N, Sugai N, Takeuchi Y, et al. (2014) A multicentre randomised trial to compare the efficacy of omeprazole versus rabeprazole in early symptom relief in patients with reflux esophagitis. J Gastroenterol 49 : 1536-1547.

23. Fass R, Chey WD, Zakko SF, Andhivarothai N, Palmer RN, et al. (2009) Clinica trial: the effects of the proton pump inhibitor dexlansoprazole MR on day time and night time heartburn in patients with non-erosive reflux disease. Aliment Pharmacol Ther 29: 1261-1272.

24. Abib E Jr, Duarte LF, Pereira R (2012) Comparative bioavailability: two pramipexole formulations in healthy volunteers after a single dose administration under fasting conditions. J Bioequiv Availab 4: 056-059.

25. Sriharsha J, Srinivasa Murthy M, Bharat Kumar D, Sravan K, Shiva kumar P, et al. (2015) Method development and validation for simultaneous estimation of dexlansoprazole and meloxicam by RP-HPLC. Pharm Anal Acta 6: 370 